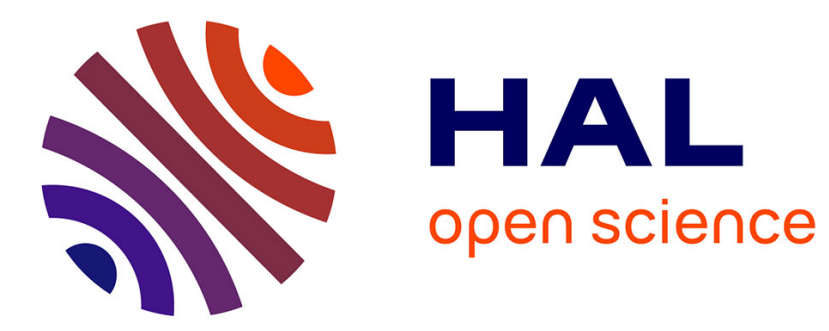

\title{
Police governance and accountability: overview of current issues
}

Dermot P. J. Walsh, Vicky Conway

\section{To cite this version:}

Dermot P. J. Walsh, Vicky Conway. Police governance and accountability: overview of current issues.

Crime, Law and Social Change, 2011, 55 (2-3), pp.61-86. 10.1007/s10611-011-9269-6 . hal-00668578

\section{HAL Id: hal-00668578 \\ https://hal.science/hal-00668578}

Submitted on 10 Feb 2012

HAL is a multi-disciplinary open access archive for the deposit and dissemination of scientific research documents, whether they are published or not. The documents may come from teaching and research institutions in France or abroad, or from public or private research centers.
L'archive ouverte pluridisciplinaire HAL, est destinée au dépôt et à la diffusion de documents scientifiques de niveau recherche, publiés ou non, émanant des établissements d'enseignement et de recherche français ou étrangers, des laboratoires publics ou privés. 


\title{
Police Governance and Accountability: Overview of Current Issues
}

\author{
Dermot P.J. Walsh and Vicky Conway
}

\section{The broad context}

The challenges of police governance and accountability have been rising up the agenda of policy makers, police chiefs, NGOs at local, national and international levels, diverse commentators and academics across several disciplines for at least the past fifty years. Initially they attracted the attention of only a small subgroup within the broader specialisation of crime and policing. Very quickly, however, the subject has grown into a significant industry generating a substantial body of deliberation and literature, in the form of: legislation, case law, codes, guidelines, reports of investigations and inquiries, policy reports, conference papers and critical commentary, all of which are continuing to expand rapidly.

The reasons for this interest and growth are not hard to find. Policing itself has changed immensely over the past fifty years in response to the demands imposed upon it by an increasingly diverse, technological, urbanised, globalised, mobile, sophisticated, rights-conscious and knowledge-based society [12, 75, 141, 158, 185, 202]. This, in turn, is reflected in developments such as: a growth in coercive police powers and functions [185, 201]; the deployment of new technologies [150, 261]; a shift towards intelligence based, problem oriented and proactive policing strategies $[31,52,78,91,99,232]$; the development of highly trained and heavily armed combat units [145, 241, 244, 245]; a trend towards arming the rank and file with lethal and semi-lethal weaponry in those forces which had been characterised by their unarmed status [145, 241, 244, 245]; an expanding range of 'police' organisations; the development of distinct specialisations within the police organisation; ${ }^{1}$ the blurring of the traditional distinction between civil policing and security [20, 109, 115, 140, 146, 165]; the growth of private sector policing [35, 57, 114, 121, 231, 238, 246, 262,], and a greater input from the private sector in the delivery of a policing service (plural policing) $[8,22,56,119,126,136,138,170,228]$; the growth in direct cross-border cooperation between police forces $[5,6,7,23,53,139,172,177,196,211,212,213$, $214,216,247]$; the development of transnational police organisations $[4,66]$; the adoption of managerial strategies and methods from private sector business organisations ${ }^{2}$ advances in the education and training methods of police recruits and personnel, together with an emphasis on third and fourth level qualifications as the norm for upwardly mobile police officers $[2,130]$; increasing reliance on the promulgation and enforcement of professional and ethical standards in all aspects of

Professor Dermot P.J. Walsh, University of Limerick

Dermot.Walsh@ul.ie

Dr. Vicky Conway, Queen's University of Belfast, Northern Ireland V.Conway@qub.ac.uk

1 Most noticeable in the policing of narcotics, gangs, terrorism, sexual violence and young offenders. See, for example, [149].

2 Terms such as: 'police service', users/clients, performance indicators and league tables are now standard. See [34, 84, 104, 202, 240, 243, 255]. 
policing $[59,71,129,169,171]$; the development of internal affairs units and 'whistle-blowing' procedures; ${ }^{3}$ the growth and expansion of civilian oversight mechanisms [16, 85, 89, 105, 133, 143, 148, 200, 223, 254]; and a drive towards central government control in some jurisdictions where tradition favoured regional and/or local control [94, 98, 144, 248].

Of particular note over the past fifty years has been the spectacular growth in laws and procedures to render the police accountable for their policies, practices, acts and decisions $[9,14,45,70,75,111,117,154,142,160,218,248]$. Accountability in this context, and for the purposes of this collection of essays as a whole, is being used loosely to encompass all procedures and methods which can be deployed to render an individual police officer, and the police authority as whole, answerable to another person or body whether that person or body is located inside or outside the police force in question. ${ }^{4}$ Accordingly, the relevant laws and procedures include, but are not confined to, a bewildering mixture of: administrative mechanisms for handling citizen complaints; civil actions and criminal prosecutions in the courts; the exclusion of improperly obtained evidence in criminal trials; internal disciplinary procedures; whistle-blowing mechanisms; judicial inquiries; inspectorates overseeing professional standards; local police-community consultation fora; and democratic oversight from local/regional assemblies and national parliaments.

Governance is a less familiar term than accountability in the policing literature and discourse [74]. ${ }^{5}$ In some respects this is surprising in that it can be defined broadly as encompassing the procedures and methods aimed at ensuring the efficient discharge of the policing function. As such, it includes key management issues such as: policy formation and implementation; the determination of priorities and strategies; deployment choices; the allocation of resources; the maintenance of standards; and internal discipline. More broadly, it includes the interaction with government and other external bodies in the context of formal accountability processes. It follows that governance can be associated with the promotion of values such as transparency, responsiveness and the maintenance of professional, ethical and human rights standards in policing. It must also be appreciated, however, that the instruments and processes of governance can be used to deploy the police as a tool of repression, and ultimately as the facilitator of a police state [46]. ${ }^{6}$

Inevitability there is a close relationship between governance and accountability; albeit a relationship that is untidy and ill-defined. While the latter cannot be viewed simply as an exclusive component of the former, it also cannot be discussed sensibly in isolation from it. Similarly, any discussion of governance which excluded

3 Both professional standards units and internal affairs units have become commonplace in efforts to combat police corruption. They can be found across police forces in most western liberal democracies. See, for example, [75; ch.8, 180, 257, 260].

$4 \quad$ For essays on accountability in criminal justice generally, and policing in particular, see [228]. For a wider perspective, see [64].

5 Lawrence Lustgarten's seminal text The Governance of the Police in 1986 appears to be the first to use the term prominently in the policing context. It now features much more regularly. See, for example [30, 68, 72, 73, 112, 117, 120, 125, 139, 164, 204].

$6 \quad$ It has been argued that this occurred in England and Wales during the 1980s, particularly with the policing of the miners' strikes when it was alleged that the police were heavily politicised; see [208, 237] and, more generally, [32]. For consideration of similar issues elsewhere, see $[169,240]$. 
accountability would be strained and artificial. For the purposes of the essays in this collection it is not necessary to seek a more refined definition of the two terms or to identify precise distinctions between them. The focus throughout is on accountability per se, and on the accountability aspects of governance. Accordingly, when the terms are used conjunctively, they should be understood in that sense. Where 'governance' is used by itself, it will often be clear from the context whether it is meant to be interpreted more narrowly. In other situations still, the lack of clarity between the terms will be the subject of discussion.

Governance and accountability methods and processes have always served a range of objectives in policing. These include: legitimacy, the maintenance of democratic values, the protection of human rights, transparency, the promotion of force efficiency and discipline and the enhancement of police community relations which, in turn, can improve the capacity of police bodies to discharge their functions $[15,118,167,185$, $204,251]$. When viewed in isolation, the pace and scale of reform in these areas over the past fifty years are truly impressive; especially, but not exclusively, across many western liberal democracies. ${ }^{7}$ It must be remembered, however, that they are only one side of the coin. On the other side is the rapid and parallel growth of police powers, organisation, methods, technologies and resources, particularly over the past decade in the context of a perceived heightened risk of terrorism. While these are meant to be deployed for the protection of the human rights of the individual and the overall common good, they can very readily produce the opposite effect. ${ }^{8}$ It is largely the strength and deployment of governance and accountability mechanisms that determine which will prevail. The key question, therefore, is whether these mechanisms are developing with sufficient speed and in the appropriate form and content to keep pace with or outstrip, the countervailing forces. ${ }^{9}$ Unfortunately, it would appear that the age old problems of police corruption and the abuse of power have not been eradicated; even in those jurisdictions which might be considered to be among the more advanced in the science of police governance and accountability [17, $129,157,162,182]$. High profile incidents and patterns of police corruption, excess and inefficiency continue to feature, in jurisdictions such as: Ireland [49, 108, 187, 191, 192, 193, 251], United Kingdom, ${ }^{10}$ France, ${ }^{11}$ the Netherlands [182; ch.4],

$7 \quad$ For discussion of the challenges facing the establishment of the liberal democratic model in a range of developing countries, see [102].

8 A topical example is the British government's policy on the retention of DNA profiles on its database of all persons suspected of crime, in the name of enhancing the capacity of the police to fight crime. Its approach was found by the European Court of Human Rights to be in breach of the Convention right to privacy in $S$ and Marper $v$. UK 30562/04 and 30566/04 $\left(4^{\text {th }}\right.$ December 2008). Also worth noting are the British anti-terrorist police powers of stop and search which the European Court of Human Rights also found to be in breach of the Convention right to privacy as they were too broad and indiscriminate in nature; see Gillan $v$ United Kingdom 4158/05 (12 ${ }^{\text {th }}$ January 2010). For a discussion of this debate in the Irish context where law and order politics have prevailed in the context of growing concerns over so-called gangland crime, see [51, 95, 151]. The major examples in recent years have concerned: the false confession cases of the Birmingham Six, Guildford Four and Maguire Seven; the corrupt activities of the WestMidland Serious Crime Squad, racism in the Stephen Lawrence murder investigation by the London Metropolitan Police; and the fatal shooting of Jean Charles de Menezes by a firearms unit of the London Metropolitan Police. See, generally [183; ch.5].

11 Police in France have been the subject of serious claims of abuse and violence, with Amnesty International expressing concern, in particular, over the treatment of ethnic minorities in the country. See http://www.amnesty.org/en/news-and-updates/report/police-abuse-goesunchecked-france-20090402 accessed on 11 May 2010. 
USA, ${ }^{12}$ Canada [14, 40], Australia [188, 69], ${ }^{13}$ and New Zealand [198]. Indeed these take on an almost cyclical pattern, recurring with alarming regularity, even after substantial reform. ${ }^{14}$ The volume of complaints and litigation against the police is steadily increasing in many countries. ${ }^{15}$

It would appear, therefore, that there is still a lot of work to be done in developing and refining our police governance and accountability methods. Unfortunately the nature and complexity of the task and issues are still depressingly familiar. To these must be added some new challenges presented by the rapid changes being experienced by policing in an increasingly complex, technological, urbanised, uncertain and globalised world. ${ }^{16}$

\section{Citizen complaints}

Few topics in police governance and accountability have generated more initiatives, analysis and debate in recent decades than the handling of citizen complaints against the police. ${ }^{17}$ A key challenge is how to deliver satisfaction for genuine complainants and overall public confidence in the system, without unduly jeopardising essentials such as police confidence and cooperation and the effective use of resources. While complete or substantial independence in the handling of complaints is widely, and reasonably, perceived as essential to public confidence, it is not sufficient in itself to overcome the inherent difficulties presented by the task of determining the truth in many categories of disputed interactions between citizen and police officer [86]. To this may be added the potential adverse effects of external independent machinery on police morale, the capacity of police management to assert their authority and discipline throughout the force and, of course, the constraints imposed by limited resources [50, 200]. Even if it is possible to devise an ideal procedure in theory, it will still have to operate in the real world where it will be subject to the distorting influences of institutional and other vested interests [85, 89]. Compensatory adjustments, and even more fundamental reforms, will always be required to respond to changes in policing tactics and challenges. It quickly becomes apparent that the task of delivering accountability even for basic 'run of the mill' complaints is not amenable to a ready resolution, and should instead be viewed as an ongoing process of reform and development to adapt to changing structures and contexts. ${ }^{18}$

\footnotetext{
12 New York has seen the Knapp Commission in the 1970s and the Mollen Commission in the 1990s. Drug corruption has been found in Cleveland, New Jersey, Texas and Detroit. In the late 1990s the Rampart scandal in LA centred on its anti-gang unit. See also [183: ch.3; 222]. Western Australia appointed a Royal Commission in 2002 to investigate the death of a youth in custody. In the mid-1990s New South Wales was hit by a corruption scandal which resulted in the establishment of the Wood Commission.

14 The cyclical nature of police corruption has been documented; see [167, 184].

15 Ireland, for example, has seen a doubling of complaint numbers since the establishment of its police Ombudsman Commission in 2007. England and Wales has reported similar increases since the creation of the Independent Police Complaints Commission The difficulties posed for policing by modern and post-modern society are well documented $[13,21,159,185]$. The body of scholarly work on this topic is particularly large but some key readings can be identified [16, 85, 89, 105, 134, 144, 149, 224, 226, 255, 257].

18 Chan has outlined in detail the need for police reform to be on ongoing process [44]. McLaughlin and Johansen have suggested that in the light of the failures of traditional mechanisms, it may be worth considering the use of restorative justice practices in the resolution of complaints against the police [160].
} 
The task becomes particularly complex when the issue concerns police policies or practices which are provoking concern generally, or for distinct groups or communities. ${ }^{19}$ In some respects it is even more important to deal effectively with these, as they are likely to have an extensive impact on public confidence in the police and on the nature and quality of the police service being delivered [100; ch.18]. They can also account for a significant proportion of the complaints lodged by individuals. In the worst case scenarios corrupt policies or practices can be tackled effectively by public judicial inquiries (see later). Not only can these provide a foundation for remedial reform, but they can have cathartic and confidence enhancing effects. ${ }^{20}$ On the other hand, they are also a reflection of system failure over many years; and, in particular, the failure of the administrative complaint mechanisms to pick up on and redress corrupt or ineffective policies and practices much earlier before they had undermined public confidence in policing as a whole. ${ }^{21}$ This failure is frequently magnified by the time taken to complete an inquiry $[49,206]$. Equally, the judicial inquiries present many of the familiar challenges of the citizen complaints procedures, sometimes in a more acute form. ${ }^{22}$ Alternative approaches, based on police community consultation processes and democratic scrutiny, present their own problems in this context, as will be noted later.

The nature and scale of the challenges in the complaints area are reflected in the tortuous history of the growth of independent civilian review mechanisms [85 89]. Not much more than fifty years ago, external involvement in the administrative investigation and determination of complaints against the police was unknown in common law jurisdictions. ${ }^{23}$ Such complaints were handled either as internal disciplinary matters by the police force itself [252; chs.7\&8], or through civil or criminal actions in the courts at the suit of the civilian complainants or the State [80, 110, 222, 224, 252; chs.10\&11]. Even where the State was the complainant, the investigation was still carried out by the police themselves. Now there is quite an array of 'independent' mechanisms, reflecting the ebb and flow of struggles with and within police organisations, governments and other pressure groups. ${ }^{24}$ In a few jurisdictions an independent body has been established with the powers and resources specifically to investigate a very wide range of citizen complaints or matters of concern that have come to its attention. ${ }^{25}$ More typically, such 'independent' bodies must rely on the police themselves to perform the actual investigation in respect of

19 This often arises in relation to the policing of ethnic minorities in a country, the policing of young people, or in some conflict societies, such as Northern Ireland, the disproportionate policing of one religious sector of the community [26, 27, 41, 43, 96, 148, 165]. Much stock is placed in the ability of Tribunals to unearth the truth and expose wrongdoing through independent means. See [33, 135, 250]. The Morris Tribunal in Ireland acknowledged that one of the precipitating factors in the establishment of the tribunal was the inability of the existing complaints mechanism to deal with the scale and nature of the abuses which were occurring [194].

22 See, for example, [24].

23 For an account of reliance on the traditional internal disciplinary model in American police forces, see [18; pp.500-509].

24 W.A. Kerstetter classified the options as civilian review, civilian input and civilian monitor [128]. A. Goldsmith identifies a broad range of categories including: traditional (internally dealt with), civilian in-house, civilian external supervision, civilian external investigation, civilian external investigatory/adjudicative and police investigatory on behalf of civilian external agency [85].

25 The Office of the Police Ombudsman in Northern Ireland conducts all investigations itself[76]. 
most, or all, complaints, with the bodies providing a supervisory or review input that varies in detail from one jurisdiction to another. ${ }^{26}$ Other models operate as appeal mechanisms from the internal police investigation and determination, ${ }^{27}$ while several European continental jurisdictions rely on the standard administrative ombudsman model. ${ }^{28}$ The net effect of these developments is that citizen complaints against the police are much less likely to be received, investigated and dealt with wholly within the police organisation itself. The police organisation has had to accept the concept of external independent involvement in its own internal management.

\section{The courts}

The picture is further complicated by the fact that the administrative complaints and discipline mechanisms are part of a larger framework of remedial processes. The courts, for example, are often cited as the citizen's fundamental protection against corrupt and negligent police policies, practices, acts and omissions [47]. In many Western liberal democracies, they are perceived as offering a measure of independence and authority, which can overcome some of the weaknesses of independent administrative complaints procedures when dealing with disputes between the citizen and the police. In their civil jurisdiction they can provide the individual victim of police abuse or neglect with a remedy in damages, and/or in the form of binding orders declaring and protecting the rights and interests of the individual in the matter in question [47, 67]. Similarly, they have the capacity directly to shape police policies and practices in their judicial review jurisdiction. In their criminal jurisdiction they can punish individual police officers for treating citizens in a manner that breaches the criminal law. There may also be scope to punish police infractions indirectly in criminal trials by the application of an exclusionary rule to police evidence that has been gathered improperly (see later).

It does not follow, however, that the courts offer a comprehensive and reliable source of remedies for improper police acts, omissions, policies and practices. Unfortunately, they suffer from their own complications and limitations concerning: jurisdiction, procedure, access, cost and delay. ${ }^{29}$ Nor is it beneficial for public confidence in the police to have citizens engaging in adversarial conflict with police officers [224]. Just as with the complaints procedures, therefore, there is need for ongoing theorising, research and experimentation in the drive to enhance their capacity to deliver accountability dividends.

\section{Judicial inquiries}

Judicial inquiries into policing matters of public concern have emerged alongside the complaints procedures in recent years as another primary instrument of police accountability. Unlike courts, with which they are often confused, the inquiries do not offer direct remedies for police corruption and abuse, or make findings of innocence

\footnotetext{
26 The Garda Síochána Ombudsman Commission could potentially handle all investigations itself, but a large number are being 'leased back' to the police to conduct the investigations. The Commission can choose whether or not to supervise such investigations [50, 254]. It should be noted that the European Court of Human Rights has ruled that where Convention rights have been breached it would also be a breach of the right to an effective remedy not to hold an independent investigation: Govell v. UK [1998] EHRLR 101. This is the case in countries such as: Austria, Denmark, Finland, Sweden, Greece, Latvia, Lithuania and the Netherlands.

See C. Foote [80]. While it may be dated in terms of when it was published many of the critical observations are still very pertinent today.
} 
or guilt. They are essentially fact finding mechanisms $[93,190]$. In the face of serious allegations of police corruption and/or abuse that have given rise to public concern, they will establish and publicise the facts to a level that cannot always be achieved by the administrative procedures or even the courts $[83,101]$. While they do not deliver immediate remedies for victims of the corruption or neglect, they can deliver valuable benefits by way of restoring an individual's sense of dignity and reputation, leaving her with a sense of vindication and, perhaps most important of all, reassuring her that she was able to secure a public accounting from the police for the wrongs inflicted by them. More broadly, the inquiries contribute immensely to the wider goals of transparency and accountability [197]. Their reports and findings are often the catalyst for public confidence enhancing reforms in other areas such as: complaints procedures; democratic oversight mechanisms; professional and ethical standards; and police procedures. The Knapp Commission in New York in the early 1970s, for example, exposed widespread corruption in the NYPD and sparked a thorough overhaul of the system as well as a 'clean out' of officers at all levels. New leadership brought fresh thinking [130, 182]. The MacPherson Report in the UK in the late 1990s exposed institutional racism in London's Metropolitan Police and resulted in fundamental reforms in training, investigation of crimes and supervision of officers. It also brought vindication for the family of Stephen Lawrence who had long fought the handling of the investigation into his death [103, 147, 199]. The recent Morris Tribunal of Inquiry conducted the most detailed and penetrating exposé of police corruption in Ireland since the establishment of the State in 1922 [49, 193]. Its hearings and reports are associated with the most fundamental governance and accountability reforms in the Garda Síochána in the history of the force.

As with the complaints procedures and the courts, judicial inquiries bring their own challenges and limitations. Their establishment can be haphazard, dependant as it is on sufficient political pressure being brought on the government of the day which may have a vested interest in covering up the matters to be investigated. In any individual case the inquiry's capacity to deliver its accountability potential is dependant on its terms of reference which are determined by the government of the day. Frequently, in the operation of the inquiry there is a tension between the need to uncover the truth efficiently and quickly on the one hand, with the need to do justice to the issues and persons under investigation on the other. There have been occasions when, arguably, the pursuit of the latter has been jeopardised and perhaps even seriously undermined by insufficient attention being given to the former. The Bloody Sunday Tribunal of Inquiry, for example, took twelve years and cost about $€ 200$ million to deliver a report of over 5,000 pages, almost forty years after the event [249]. Since it concerned the actions of British soldiers in shooting dead 13 unarmed civilians on the streets of a city in the United Kingdom, it is understandable that no effort and expense should be spared in uncovering the full truth to the extent that that is possible. It is questionable, however, whether such an exercise could ever be justified in terms of practical accountability dividends in the policing of a liberal democracy.

\section{Human rights and professional standards}

Enhancing police governance and accountability cannot be left solely to the courts, administrative complaints mechanisms and judicial inquiries. Measures aimed at preventing the occasion for complaints arising in the first place are just as important. To this end, much attention has been given in recent years to the promulgation and 
enforcement of human rights and professional standards across all aspects of police organisation, management, policies and practices, as well as in the accountability mechanisms themselves [3, 28, 58, 59, 129, 169, 171, 217, 237, 251]. In some common law jurisdictions these can be traced back to the instructions given by the chiefs of police on the establishment of the first organised police forces. A most famous example is the instructions given to the constables of the London Metropolitan Police force by the first Commissioners, Rowan and Mayne, on the occasion of the force becoming operational in 1829 [186; pp.135-140]. ${ }^{30}$ An equally famous example also emanating from England, albeit from a different source, is the Judges Rules which were first handed down in $1912[116,132 ; \mathrm{ch} .8] .{ }^{31}$ These focus narrowly on the procedures that a constable should follow in the critically important function of taking a statement from a suspect, and associated matters. The US Supreme Court decision in Miranda $v$ Arizona ${ }^{32}$ in the mid-1960s imposed similar standards on police with a view to protecting civil liberties.

Today, standards applicable to all aspects of policing emanate from a range of sources, most notably: the legislature, the executive, the courts, police chiefs and police inspectorates. While each jurisdiction has had to wrestle with its own challenges and develop the standards best suited to its own circumstances, it cannot ignore the impact of developments elsewhere. With the increasing traffic in police cooperation across borders, for example, come increased needs and demands for compatibility across jurisdictions. Not surprisingly, multinational bodies such as the UN, the Council of Europe and the European Union, are beginning to respond to these needs with the setting of basic standards across all aspects of police governance and accountability. Primary sources are: the International Covenant on Civil and Political Rights, the European Convention on Human Rights, the UN Code of Conduct for Law Enforcement Officials, the UN Basic Principles on the Use of Force and Firearms by Law Enforcement Officials, the Council of Europe's Declaration on the Police and, indirectly, the jurisprudence of the European Court of Human Rights [60, 251; pt.1]. Possibly the most comprehensive international source is the Council of Europe's Code of Police Ethics [54]. ${ }^{33}$ In practice, the individual police officer will usually have the benefit of an internally generated code or codes which draw on all of these sources and others to set out the professional, ethical and human rights standards that should inform the officer's conduct and performance. ${ }^{34}$

$30 \quad$ These helped instil the principle of policing by consent in the foundation of organised police forces in Britain. They were adopted in similar terms by the early Commissioners of Ireland's Garda Síochána when it was first established in 1922; see [29; pp.80-81 and 117]. The Rules were also adopted in Ireland and Australia, but have since been replaced in the United Kingdom by the Codes in the Police and Criminal Evidence Act 1984 and related legislation.

32384 US 436 (1966). See [77]. For a comparator of these two systems, see [122].

33 The Code provides an outline of the role of the police, their basis in the rule of law and guidelines on their organisation and structure, on police action and intervention, on accountability and control of the police and on research and international cooperation. Many police forces now specifically employ human rights officers for the purpose of developing these codes and training new recruits and officers on their content and importance. The Police Service of Northern Ireland has, for example, a page on its website dedicated to human rights and on which they have published the Human Rights Plan of Action for each year from 2006-2010 http://www.psni.police.uk/index/about-us/human_rights.htm accessed on 12 May 2010. 


\section{Exclusionary rule}

The apparent uniformity of approach in the human rights aspects masks the immense scope for difference in substance and practice, with police management, police personnel, government, victims' groups, vulnerable minority groups, human rights and civil liberties groups, distinct socio-economic groups and the public as a whole potentially having conflicting views on desirable standards across a whole range of policing matters, and even on how they should be devised. Further complications and differences arise over how standards should be enforced. Should breach of the code constitute a criminal, civil or disciplinary infraction in itself, or should it have no direct penalty consequences for the officer concerned? Particularly contentious is the use of an exclusionary rule in a criminal trial to deny the prosecution the use of evidence which has been obtained by the police in breach of the prescribed standards $[39,106,176]$. Should it be used as an instrument to promote police compliance with the appropriate standards, or should it be reserved for situations where not to exclude the evidence would result in an unfair trial and/or a miscarriage of justice? Different jurisdictions take different approaches on these matters, and even within some individual jurisdictions there is still acute debate on the appropriate approach [62, $123,174,219,235]^{35}$

\section{Inspectorate}

By contrast, the potential contribution of an inspectorate in promoting and overseeing compliance with prescribed standards has proved less controversial. Even here, however, there is room for ongoing argument over basic matters such as status, composition, remit and modus operandi. In England, for example, the inspectorate concept was first introduced to policing in 1856, essentially as a device through which central government could purchase a degree of influence over the locally controlled constabularies in return for a central contribution to constabulary budgets [233; p.101]. ${ }^{36}$ Inevitably, this has blurred the distinction between the maintenance of professional and ethical standards and political control. As the doctrine of police independence from political authority gained a foothold in England and some other common law jurisdictions (see later), the political control dimension of the inspectorate concept has strengthened and become more controversial.

\section{Democratic governance and accountability}

The whole area of police-community consultation and democratic scrutiny provides some of the most acute challenges, even in liberal democracies. Much of the problem stems from distinctive aspects of the police status and function. ${ }^{37}$ Police officers, for example, play a direct and critical role in protecting the fundamental rights of the individual, communities and the State to safety and security. Paradoxically, one of their primary methods for discharging that is by encroaching intrusively on the human

35 The UK Courts have clearly stated that the purpose of the exclusionary rule is specifically to protect the rights of the accused, not to punish police officers or deter the use of unlawful methods. See [124].

Her Majesty's Inspectorate of Constabularies continues to conduct independent inspections of all police forces and policing activities in England, Wales and Northern Ireland. They also chair the Police Performance Steering Group. A separate Inspectorate of Constabularies exists in Scotland. Northern Ireland is further subjected to inspections by Criminal Justice Inspection Northern Ireland.

37 Inevitably these can vary from society to society. The focus in these essays is on western style liberal democracies. For a comparative selection of different models of policing across the world, see [157]. 
rights of individuals. ${ }^{38}$ In most common law jurisdictions this extends to exerting a key influence on the administration of justice through their discretionary powers of decision-making in matters such as: arrest; detention; questioning; taking bodily samples; entry, search and seizure; and charging [17, 162: pt.2]. Nevertheless, the police form part of the executive branch of government, and much of what they do can be understood as the delivery of an executive service without which the proper functioning of our complex urban society would be inconceivable. It would be reasonable to suppose, therefore, that they should be subject to the norms of democratic governance and control over the executive. In particular, the standard mechanisms of democratic scrutiny over the executive should help ensure that they remain accountable to the State and to the people on whose behalf they exercise their extraordinary powers and discharge their sensitive role. Unacceptable policies and actions should be challengeable by the elected representatives of the people making representations to the relevant local, regional or national government authorities who in turn can pursue the necessary changes with the police authorities.

In practice, of course, several factors intervene to dilute or distort the application of the traditional democratic accountability processes to the police relative to most other areas of the executive in multi-party democracies. Of particular note in many common law jurisdictions is the concept of police independence. Stemming from factors such as the peculiar common law origins of the constable, the discretionary powers of police officers and their distinctive role in the administration of justice, the idea has taken root that the police enjoy a measure of independence in the discharge of their essential functions [189, 230, 252; chs.3-5]. The nature and scope of this independence is surprisingly ill-defined and uncertain, but it is sufficiently settled to the extent that instances of external political intervention in what might broadly be termed operational policing policies and/or decision-making are guaranteed to generate serious expressions of concern about improper political interference in policing [145, 155, 145, 229].

Given the sensitive nature of aspects of the police function, it is easy to appreciate why there should be a concern to protect the police against the full rigours of democratic governance and accountability as applied to the executive generally. The failure to do so would run the risk of politicising safety, security and justice. The prospect of the police being required, whether directly or indirectly, to apply vindictive or preferential law enforcement treatment to distinct groups or individuals for politically partisan ends, is clearly intolerable in any liberal democracy based on respect for human rights. On the other hand, to insulate the police too heavily against democratic direction and accountability will only lay the foundations for the worst excesses of a police state. The open-ended challenge, therefore, is to devise methods which strike a reasonable accommodation between these conflicting tensions.

An increasingly common approach to the democratic accountability challenge is to democratise policing in the sense of making it everybody's business. This can range from the establishment of local police - community consultation fora, to recruiting members of the public to engage in policing directly as reserve or special police officers or indirectly as part of neighbourhood watch type arrangements. In between,

38 For discussion of the sources, characteristics and tensions at the heart of these conflicting police roles, see [159]. More generally, see [25, 36; pp. 69-82]. 
are devices such as lay-station visitors where designated members of the community are expected to pay occasional visits on an ad hoc basis to a police station to check on the treatment of suspects who happen to be detained there at the time of their visit. Sometimes referred to as 'plural policing', these developments bring with them a whole new set of challenges for police governance and accountability $[8,22,56,119$, $126,136,137,169,227]$. The consultation fora, for example, raise issues such as: status, composition, appointment/removal, remit, powers, modus operandi, accountability and sustainability. As the police entity itself becomes more extensive and diffuse through broader public participation, it becomes increasingly difficult to identify the targets of governance and accountability, to prescribe suitable policing methods and to assess their impact [14, 117, 160, 218].

\section{Privatisation}

Closely related to the idea of plural policing is privatisation $[35,57,61,114,121$, $209,226,238,262]$. While it has been around for a long time in policing, primarily in the form of the private security industry serving the needs of private sector commercial and industrial clients, it is rapidly expanding into more traditional public sector policing domains. In some jurisdictions, for example, exclusive residential developments frequently have their own private police service in addition to the State service. Similarly, some States are hiving off to the private sector disparate functions previously discharged by the public police service. As Stenning has very aptly pointed out, private policing operations and personnel are not above the law or accountability [231]. They are subject to a number of accountability mechanisms. Nevertheless, these may not always be, or operate in the same manner as, those applicable to public sector policing $[63,210]$. Certainly, when privately employed, they are not subject directly to international human rights requirements. Moreover, private sector policing brings its own distinct governance and accountability challenges and methods [65, $113,127,181,220]$. What these are, how they can be addressed and how they interact with governance and accountability methods devised for public sector policing provide yet another major field of research and debate.

\section{Internal discipline and culture}

The debate on the mechanics of police governance and accountability must not focus solely on the checks and balances external to the police organisation itself. Internal aspects are also important. ${ }^{39}$ The interactions and tensions between internal police cultures and the police governance and accountability processes, for example, have been a lively and fruitful source of incisive research, analysis and opinion over the past fifty years $[43,55,81,87,175,179,185,242,258] .{ }^{40}$ Not surprisingly, the literature in this area is still offering new insights and arguments as it struggles to keep pace with the dynamics of policing and society in the twenty first century [142, $158,182,199,259]$. More specific, but equally important in this context, is the operation of internal disciplinary mechanisms [75; ch.8]. In many respects they represent the fusion of governance and accountability. They provide essential tools for police management to deliver an efficient, disciplined and effective police force and service. They also provide an essential means for realising external accountability through the courts, complaints system, democratic process and inspectorate, and for

39 This was highlighted as particularly important by the Patten Commission; see [107].

40 In Ireland, the reports of the Morris Tribunal of Inquiry into police corruption offer a rich resource of materials on the negative impact of internal police culture on the maintenance of discipline; see [49, 194]. 
giving effect to the legitimate requirements emanating from these sources. It is hardly an exaggeration to say that without a developed system of internal discipline, there can be no meaningful police governance and accountability.

As with all other areas of police governance and accountability, internal discipline presents its own ongoing tensions and challenges [171]. The composition and/or implementation of internal disciplinary powers and processes can play a critical role in determining whether an individual police force is perceived or expressed generally as an efficient and progressive organisation committed to upholding and protecting human rights in a reasonable and balanced manner, as an inefficient and oppressive tool of terror, as something in between or as a combination of elements of both. Even in the first of these situations, there can be tensions between internal discipline and external accountability; most notably in the struggle over the extent to which citizen complaints against the police should be handled independently of the police. Also, within the police organisation itself there can be tensions between the views of police management on what is necessary, and those of police personnel on what is fair [194]. Further complications arise from the fact that internal disciplinary mechanisms and processes can, and do, extend beyond the traditional investigation, hearing and punishment procedures to include elements such as whistle-blowing procedures and proactive operations by internal affairs units. More broadly, internal discipline cannot be wholly divorced from more general governance issues including: appointments, promotions, pay and conditions, performance management, and the roles of the representative bodies and machinery for negotiation between police management and government on the one hand and the rank and file on the other. It can be no surprise, therefore, that internal discipline comprises a huge and complex dimension of the police governance and accountability debate.

\section{Cross-border and transnational policing}

Finally, there are the complex and acute governance and accountability issues presented by the growth of cross-border policing, overseas policing missions to conflict zones, training of police in emerging States and transnational policing [4, 5, $6,7,23,53,88,138,171,176,195,210,211,212,213,215,246]$. The rapid advances in travel and information technology have revolutionised the global free movement of people, business, finance, goods, services and ideas. Within the European Union this effect has been accentuated by the dismantling of internal legal and political barriers. Undoubtedly, these advances have produced, and are continuing to produce, immense economic, social, cultural and political benefits. By the same token, however, they open up new opportunities for crime and terrorism, which are evolving and expanding rapidly $[6,82,173]$. Equally, they provoke economic, social, political and environmental tensions, all of which have the capacity to trigger a diverse range of public safety and order issues [37, 38, 140]. All of these developments present new and complex challenges for policing; not least because they entail policing in a transnational context $[1,6,68,133 ; 137,215]$.

The methods devised for policing within a single politico-legal jurisdiction will not always be suitable to deal with the challenges presented by policing operations that span one or more jurisdictional boundaries, especially when those boundaries are sovereign State borders. Machinery that is struggling to cope with the governance and accountability challenges presented by the domestic operations of home based police forces may well prove seriously deficient when confronted with the formers' activities 
on other sovereign territories, or domestic operations by foreign based police forces. Further novel challenges are presented by the growth of multi-jurisdictional police teams such as joint investigation teams within the European Union [178, 196, 205], or multi-national police teams associated with UN peace-keeping operations in troubled parts of the world $[10,42,90,92,97]$. Since these are a relatively new phenomena, the research and debate on suitable governance and accountability mechanisms are still in their infancy $[11,48,79,88 ; 151,161,208]$. In addition to the familiar challenges presented by domestic policing, these transnational developments present the complication of governance and accountability in an environment where the policing operations are detached from the established framework and processes of a sovereign government, and yet amenable to the influence of powerful global vested interests $[19,234]$.

\section{The essays}

The foregoing is inevitably a brief overview of some of the major issues facing police governance and accountability in a human rights sensitive liberal democracy during a time of rapid social, political, economic, technological and cultural change.

Nevertheless, it confirms that the field for research and debate is immense, diverse, and continuously evolving in response to new ideas and challenges. Already it benefits from a rich literature which must grow in response to the pace of change in police, policing and the policing context. This collection of essays is a contribution to that need. Individually and collectively, they respond to many of the key issues from the vantage point of the latest research and ideas from across many jurisdictions.

\section{Local police community engagement}

The governance and accountability of policing at the local level present many diverse challenges which can vary from one locale to another. Jan Terpstra and Mark Brunger in their separate essays examine attempts to render local policing amenable to the needs and wishes of the community in parts of the Netherlands and Northern Ireland respectively.

Terpstra sees local accountability as one of four different types of police governance and accountability in the Netherlands; the others being: traditional-hierarchical, professional and managerial. From the perspective of the community police officers these present conflicting demands which require different coping strategies. Based on a recent ethnographic study on neighbourhood police officers in rural and urban areas, Terpstra concluded that one such strategy was to neutralise or marginalise the voice of the local community in shaping police priorities and strategies. Local democratic control of the police is often smothered by the competing professional, managerial, cultural and central government forces. He found that this has the effect of putting distance between police offices and citizens, and even creating a demand for the engagement of private sector patrol officers who are more responsive to the needs and wishes of the local community.

In his essay, Brunger examines efforts in Northern Ireland to use public meetings to enhance interaction and dialogue between the police and local communities. His discussion focuses on one particular partnership model, Partners and Community Acting Together (PACT). Tracing the development of this model throughout the United Kingdom, and drawing on rich empirical data, he considers the complexities of implementing it in a post-conflict setting where community policing has been 
identified as weak. His analysis is supported by qualitative data on the attitudes of the police officers involved in this work, and assessments based on attendance at public meetings. He concludes that the public meetings are used essentially by the police in a symbolic way to convey the appearance of engagement, and that they may be achieving little in terms of having an impact on crime reduction.

\section{Democratisation and governance}

In his essay, Kenneth Scott addresses the practical aspects of police governance in his analysis of recent developments in the structural relationship between government and police in Scotland. This is a subject that has too frequently been overshadowed by the popular focus on English developments. Scott's contribution is all the more valuable for his sharp focus on post-devolution developments in Scotland which bring out the comparisons and contrasts with England and Wales. He argues that the Scottish approach is distinctive for its combination of enhanced transparency and a more 'hands-on' approach to government control of policing. He cautions, however, that it is still too early to predict the longer-term impact of these developments on oversight of the police in Scotland.

\section{Juvenile Justice and Policing}

Dealing with young people who have come, or who are at risk of coming, into conflict with the criminal law presents special challenges for the police. Increasingly, they are expected to assume responsibility not just for the investigation and detection of crimes committed by young people, but also for the diversion of the offenders and potential offenders away from the formal criminal justice system. Inevitability this can result in the police having to combine their traditional functions with those of prosecutor, judge and probation officer with all of the complex and conflicting issues that they present for police governance and accountability. Ursula Kilkelly and Philip Smyth address these issues in their respective papers on aspects of the Irish juvenile diversion programme. This programme started informally in the early 1960 s and was placed on a statutory footing in 2001. It applies to children between 12 and 18 years of age. Administered from within the Garda Síochána, the Programme can admit any consenting child offender and deal with his or her offence through a caution and a period of supervision by a Garda juvenile liaison officer. There is also a facility for a restorative justice event as part of the cautioning process. The operation of the programme places an extensive discretion in the hands of the gardaí involved.

Kilkelly explores how this discretion is exercised in practice in the admission and treatment of offenders referred to the programme. In particular she critiques its operation from the perspectives of international human rights standards on transparency, accountability and professionalism in juvenile justice. While she considers the programme has an essential and valuable role to play in enhancing the legitimacy of the police in the eyes of young people, she also finds considerable room for improvement in terms of transparency and accountability. In particular she

Kilkelly begins by setting out the relevant international human rights standards on transparency, accountability and professionalism in juvenile justice. She uses these as a benchmark to critique the law, policy and practice underpinning the Diversion Programme. Basing herself on a detailed analysis of its framework and operation in practice she reveals how it falls short of the international standards and, in particular, the due process rights of the children who come within its reach. She finds that the 
root of the problem lies primarily in the lack of published criteria to guide the discretionary decision-making at the several stages of the process and the lack of a credible complaint or review mechanism for the children affected. She recommends the publication of reasons for decisions taken in the exercise of Garda discretion at key stages of the process in individual cases, together with provision for review or appeal of such decisions and regular independent monitoring of the operation of the programme as a whole.

Smyth complements Kilkelly's analysis with his critical focus on how the Irish police have used their law enforcement discretion to expand their role in dealing with young offenders into territory more appropriately reserved for courts, social workers and probation officers. He shows how these essential elements of the current Diversion Programme can be traced back to the administrative police practice of cautioning which emerged in the early 1950s. Although it now rests on a statutory framework, Smyth argues, in line with Kilkelly, that the welfare benefits flowing from the Programme are being purchased at the cost of due process rights for young offenders. $\mathrm{He}$ also argues that there is a need for more custom built accountability checks and balances and greater transparency in the police role in juvenile justice.

\section{Science and technology}

Developments in science and technology have always played a significant part in shaping and changing practices across many aspects of policing. These have included advances in knowledge, such as the science of fingerprinting and DNA, to advances in computerisation and sophisticated devices to capture sounds and images. Individually, and collectively, their availability and use present new governance and accountability challenges or, at least, new variations on the established challenges. In their essay, In their essay, John McGarry and Clare Kinsella offer a very real and everyday experience of the problems that can arise in the use of computer technology (records on the Police National Computer) in the stopping and impounding of cars being driven without appropriate insurance cover in the United Kingdom. Drawing on primary research conducted with a student stopped and falsely accused of driving without insurance, they question the legality and legitimacy of the seizure power, and the legitimacy of charging owners to reclaim their property in such circumstances. They found serious grounds for concern over the legality and appropriateness of the police dispensing summary justice at the roadside under these arrangements. In particular, they stress the need for the injection of greater transparency and limits on the police discretion, including: the restriction of the seizure power to situations where there was reasonable grounds to suspect that the vehicle was being driven unlawfully; a requirement on the police to take reasonable steps to check the veracity of the driver's assertion that the car was being driven lawfully; a requirement to maintain full records of each stop, including whether it subsequently transpired that the vehicle was being driven lawfully; transparency in the calculation of any charge due for reclaiming an impounded vehicle; and a duty on the police to consider the needs of vulnerable persons affected by a vehicle seizure.

\section{Evidence and the exclusionary rule}

As indicated earlier, the laws of evidence, and the exclusionary rule in particular, can deliver important police governance and accountability dividends. By holding out the threat of excluding from the prosecution case evidence that has been obtained unconstitutionally, illegally or unfairly, evidentiary rules can promote police 
compliance with proper standards and operate as a powerful accountability mechanism. As is well established, there is considerable divergence among the courts in common law countries in the extent to which they are willing to use such rules as a tool of police governance and accountability. In their separate papers, Liz Heffernan and Yvonne Daly probe the approach of the Irish courts.

Heffernan sees the accountability potential of evidentiary rules as a by-product of the common law's concern to protect the trial rights of the accused. As the common law gradually shifted from the view that the investigation of an offence was divorced from the trial of the offender to a vision of criminal justice as a unitary seamless web, so it embraced the need for judicial scrutiny of the manner in which evidence was gathered by the police. As Heffernan explains, the Irish courts have placed a strong emphasis on the need to exclude evidence in order to protect the rights of the accused and the fairness of the trial process. Indirectly, this delivers a valuable police accountability dividend. She also argues, however, that legislative interventions and some judicial hesitancy have fuelled inconsistent and contradictory trends. There is now a pressing need for reflection on the respective roles of the legislature and the courts in this area.

Daly complements Heffernan's analysis by focusing specifically on recent Irish case law on the exclusionary rule, culminating in the Supreme Court's decision in DPP (Walsh) $v$ Cash..$^{41}$ It had been anticipated that this case would provide clarity on the status of the rule which had been called into question in the wake of the preceding High Court decision. In the event, as recounted by Daly, the Supreme Court avoided the status issue, leaving the currency of the rule in some doubt. Inevitably, this has damaged the capacity of the rule to determine Garda investigative practices. Daly's analysis is enriched by the use of comparative material and developments from other jurisdictions on the role of the criminal courts in delivering police governance

\section{Policing in international peace-keeping/building operations}

As indicated earlier, police governance and accountability challenges are even more acute in the context of policing operations which straddle jurisdictional borders, or where the police force has no established association with the domestic legal and administrative frameworks. In their essay, Jonathan Kearney, Sofia Botzios and Tom Hadden address the latter in the context of the involvement of international policing personnel in peace-keeping and peace-building missions across the globe. In particular, they tease out the difficulties in holding these personnel to account for any wrongdoing while in the host state. They attribute part of this problem directly to the status of the forces and the mission agreements which typically exempt the personnel from the jurisdiction of the host state. In addition, however, Kearney et al. expose the substantive hurdles facing disciplinary investigations or criminal proceedings once the personnel have returned to their home state. Confirming a recurring theme in this work, they situate their discussion in the context of the very serious potential for the local populations to perceive these forces as 'above the law', with serious repercussions for achieving the aims of the mission. Citing case studies from international missions, the authors consider some of the options for reform of accountability mechanisms within the political context.

\footnotetext{
$41 \quad$ [2010] IESC 1
} 


\section{Current Developments}

Concluding the collection is an examination of recent efforts to reform accountability and governance structures in one jurisdiction: the Republic of Ireland. Vicky Conway and Dermot Walsh, tying together many of the debates and issues raised throughout the rest of the collection, assess critically legislation introduced in 2005 in the wake of a landmark tribunal on policing. The Morris Tribunal which chronicled serious misconduct and negligence in a large policing division provided the most scathing criticism ever seen of the Irish police force. The reforms introduced in its wake included an independent complaints body, increased ministerial powers, Joint Policing Committees, a professional standards unit as well as an Inspectorate. While on paper much of this appears as best international practice, Conway and Walsh argue that both on paper and in implementation there are both weaknesses and lacunas.

They contend that the centralisation of power to the government has the potential to politicise the force as never before. They further expose how while the semblance of independent complaints investigation has been created the statistics published thus far by that body show that significant proportions of investigations are still conducted internally. Nor has the force manage to embed itself in a human rights framework, as required by the Good Friday Agreement. In conclusion they warn of the failure of recent efforts to both identify and addresses weaknesses in accountability and governance structures. 
Reference List

1. Aden, H. (2001). Convergence of Policing Policies and Transnational Policing in Europe. European Journal of Crime, Criminal Law and Criminal Justice, 9, 99-112.

2. An Garda Síochána. (2009). Training and Development Review Group Report. Templemore: An Garda Síochána.

3. Anderson, J. (1985). Human Rights and the Police. Police Studies:

International Review of Police Development, 8, 67.

4. Anderson, M. (1989). Policing the World: Interpol and the Politics of Police Cooperation. Oxford: Oxford University Press.

5. Anderson, M., \& Apap, J. (editors). (2002). Police and Justice Cooperation and the New European Borders. London: Kluwer Law International.

6. Anderson, M., \& den Boer, M. (1996). Policing the European Union: Theory, Law and Practice. Oxford: Oxford University Press.

7. Andreas, P. (2001). Border Games: Policing the US-Mexico Divide. Cornell, 2001.

8. Ayling, J., Grabosky, P., \& Shearing, C. (2009). Lengthening the Arm of the Law: Enhancing Police Resources in the Twenty-First Century. Cambridge: Cambridge University Press.

9. Bayley, D.H. (1983). Accountability and Control of the Police: Lessons from Britain. In Bennett, T. (editor). The Future of Policing. Cambridge: Cambridge University Press.

10. Bayley, D.H. (2006). Changing the Guard: Developing Democratic Policing Abroad. Oxford: Oxford University Press.

11. Bayley, D.H. (2001). Democratising The Police Abroad: What to Do and How to Do it. Washington DC: US Dept of Justice.

12. Bayley, D.H. (1996). Police for the Future. Oxford: Oxford University Press.

13. Bayley, D.H., \& Shearing, C. (2003). The Future of Policing. In T. Newburn (editor). Policing: Key Readings. Cullompton: Willan, ch.40.

14. Beare, M., \& Murray, T. (editors). (2007). Police and Government Relations: Who's Calling the Shots? Toronto: University of Toronto Press.

15. Beetham, D. (1991). The Legitimation of Power. London: Macmillan.

16. Beggs, J., \& Davies, H. (2009). Police Misconduct: Complaints and Public Regulation. Oxford: Oxford University Press.

17. Bell, J. (editor). (2006). Police and Policing Law. Aldershot: Ashgate.

18. Beral, H., \& Sisk, M. (1964). The Administration of Complaints by Civilians against the Police. Harvard Law Review, 77, 499.

19. Bigo, D. (2008). Global (in)Security: The Field and the Ban-opticon. In Bigo, D., \& Tsoukala, A. (editors). (2008). Terror, Insecurity and Liberty: Illiberal Practices in Liberal Regimes. London: Routledge, 10-48.

20. Bigo, D. (2006). Internal and External Aspects of Security. European Security $15,385-404$.

21. Bittner, E. (1970). The Functions of the Police in Modern Society. Maryland: National Institute of Mental Health.

22. Blackburn, S., \& Lister, S. (2005). Plural Policing: the Mixed Economy of Visible Patrols in England and Wales. Oxford: Polity Press.

23. Block, I. (2008). Combatting Organised Crime in Europe: Practicalities in Police Cooperation. Policing, 74-81. 
24. Blom-Cooper, L. (2010). What Went Wrong on Bloody Sunday: a Critique of the Saville Inquiry. Public Law, 61-78.

25. Booth, K., \& Wheeler, N.J. (2007). The Security Dilemma: Fear, Cooperation, and Trust in World Politics. Hampshire: Palgrave Macmillan.

26. Bowling, B., \& Philips, C. (2003). Policing Ethnic Minority Communities. In Newburn, T. (editor). Handbook of Policing. Cullompton: Willan.

27. Bowling, B., \& Philips, C. (2002). Racism, Crime and Justice. London: Longman.

28. Bowling, B., Philips, C., Campbell, A., \& Docking, M. (2004). Policing and Human Rights: Eliminating Discrimination, Xenophobia, Intolerance and Abuse of Power from Police Work. New York: UN Research Institute for Social Development.

29. Brady, C. (1974). Guardians of the Peace. Dublin: Mercier Press.

30. Brown, A. (1998). Police Governance in England and Wales. Cullompton: Willan.

31. Bullock, K., \& Tilley, N. (editors). (2003). Crime Reduction and Problem Oriented Policing. Cullompton: Willan.

32. Bunyan, T. (1977). The Political Police in Britain. London: Quartet Books.

33. Burton, F., \& Carlen, P. (1979). Official Discourse: On Discourse Analysis, Government Publications, Ideology and the State. London: Routledge.

34. Butler, A. (1984). Police Management. London: Gower

35. Button, M. (2007). Security Officers and Policing: Powers, Culture and Control in the Governance of Private Space. Aldershot: Ashgate.

36. Buzan, B. (1991). People, States and Fear: An Agenda for International Security Studies in the Post-Cold War Era $2^{\text {nd }}$ ed. Hemel Hempstead: Harvester Wheatsheaf.

37. Buzan, B., \& Wæver, O. (2003). Regions and Powers: The Structure of International Security. Cambridge: Cambridge University Press.

38. Buzan, B., Wæver, O., \& de Wilde, J. (1998). Security: A New Framework for Analysis. New York: Lynne Rienner.

39. Calabresi, G. (2003). The Exclusionary Rule. Harvard Journal of Law and Public Practice, 26.

40. Cameron, I. (1985). Commission of Inquiry concerning Certain Activities of the Royal Canadian Mounted Police. Second Report: "Freedom and Security under the Law". Modern Law Review, 48, 201-211.

41. Cashmore, E., \& McLaughlin, E. (1991). Out of Order? Policing Black People. London: Routlege.

42. Celador, G.C. (2005). Police Reform: Peacebuilding Through "Democratic Policing? International Peacekeeping, 12, 364-76.

43. Chan, J. (1977). Changing Police Culture: Policing in a Multi-Cultural Society. Cambridge: Cambridge University Press.

44. Chan, J. (1996). Changing Police Culture. 36, British Journal of Criminology 109-134.

45. Chan, J. Governing Police Practice: Limits of the New Accountability. British Journal of Sociology, 50, 251.

46. Chapman, B. (1970). Police State. London: Pall Mall Press.

47. Clayton, R., \& Tomlinson, H. (2004). Civil Actions against the Police $3^{\text {rd }}$ ed. London: Thomson Sweet \& Maxwell.

48. Coll, C., \& Barnett, M. (1999). Looking for a Few Good Cops: Peacekeeping, Peacebuilding and CIVPOL. International Peacekeeping, 6, 43-68. 
49. Conway, V. (2010). The Blue Wall of Silence: The Morris Tribunal and Police Accountability in Ireland. Dublin: Irish Academic Press.

50. Conway, V. (2009). A Sheep in Wolf's Clothing? Evaluating the Impact of the Garda Síochána Ombudsman Commission. Irish Jurist, 43, 109-130.

51. Conway, V., \& Mulqueen, M. (2009). The 2009 Anti-Gangland Package: Ireland's New Security Blanket? Irish Criminal Law Journal, 19, 106.

52. Cope, N. (2004). Intelligence Led Policing or Policing Led Intelligence. British Journal of Criminology, 44, 188.

53. Council of Europe. 2003). Cross-Border Cooperation in the Combatting of Organised Crime. Strasbourg: Council of Europe.

54. Council of Europe. (2002). The European Code of Police Ethics: Recommendation Rec(2001) and Explanatory Memorandum. Strasbourg: Council of Europe.

55. Crank, J.P. (1998). Understanding Police Culture. Connecticut: Anderson Publishing.

56. Crawford, A. (2008). Plural Policing in the UK: Policing beyond the Police. In Newburn, T. (editor). Handbook of Policing $2^{\text {nd }}$ ed. Cullompton: Willan, ch.7.

57. Crawford, A., \& Lister, S. (2006). Additional Security Patrols in Residential Areas: Notes from the Marketplace. Policing and Society, 16, 164-188.

58. Crawshaw, R., Cullen, S., \& Williamson, T. (2007). Human Rights and Policing $2^{\text {nd }}$ ed. Leiden: Martinus Nijhoff Publishers.

59. Crawshaw, R., Devlin, B., \& Willliamson, T. (2007). Human Rights and Policing: Standards for Good Behaviour and a Strategy for Change $2^{\text {nd }} e d$. The Hague: Kluwer Law International.

60. Crawshaw, R., \& Holmstrom, L. (editors). (2008). Essential Texts on Human Rights for the Police: a Compilation of International Instruments. Leiden: Martinus Nijhoff, 2008.

61. Cunningham, W., \& Tyler, T. (1985). Private Security and Police in America: The Hallcrest Report. University of North Carolina: Chancellor Press.

62. Daly, Y. (2009). Unconstitutionally Obtained Evidence in Ireland: Protectionism, Deterrence and the Winds of Change. Irish Criminal Law Journal, 19(2), 40.

63. Davis, R. et al. (2003). The Public Accountability of Private Police: Lessons from New York, Johannesburg and Mexico City. Policing and Society, 13, 197-210.

64. Day, P., \& Klein, R. (1987). Accountabilities: Five Public Services. London: Tavistock.

65. De Waard, J. (1999). The Private Security Industry in International Perspective. European Journal on Criminal Policy and Research. 7, 143-174.

66. Deflem, M. (2002). Policing World Society: Historical Foundations of International Police Cooperation. Oxford: Oxford University Press.

67. Del Carmen, R. (1981). An Overview of Civil and Criminal Liability of Police Officers and Departments. American Journal of Criminal Law, 33.

68. Den Boer, M. (2002). Towards an Accountability Regime for an Emerging European Police Governance. Policing and Society, 12, 275-289.

69. Dickie, J. (1988). The Road to Fitzgerald and beyond. Queensland: University of Queensland Press.

70. Dixon, D. (1997). Law and Policing. Oxford: Clarendon Press..

71. Dixon, D. (2005). The Legal Regulation of Policing. In Newburn, T. (editor). Policing: Key Readings. Cullompton: Willan, ch.37. 
72. Dixon, D. (2003). Police Governance and Official Inquiries. In Gilligan, G., \&.Pratt, J. (editors). Crime, Truth and Justice: Official Inquiry, Discourse and Knowledge. Cullompton: Willan.

73. Dupont, B. (2003). The New Face of Police Governance in Australia. Journal of Australian Studies, 27, 15-24.

74. Edwards, A. (2005). Governance. In McLaughlin, E., \& Muncie, J. (editors). The Sage Dictionary of Criminology $2^{\text {nd }}$ ed. London: Sage, 2005.

75. Edwards, C. (2005). Changing Policing Theories for $21^{\text {st }}$ Century Societies $2^{\text {nd }}$ ed. Sydney: The Federation Press.

76. Ellison, G. (2007). A Blueprint for Democratic Policing Anywhere in the World? Police Quarterly, 10, 243-269.

77. Elson, S., \& Rosset, A. (1967). Protections for the Suspect Under Miranda $v$. Arizona". Columbia Law Review, 67, 645.

78. Ericson, R.V., \& Haggerty, K. (1997). Policing the Risk Society. Oxford: Clarendon Press.

79. Ferguson, C. (2004). Police Reform, Peacekeeping and SSR: The Need for Closer Synthesis. Journal of Security Sector Management, 2.

80. Foote, C. (1954). Tort Remedies for Police Violations of Individual Rights. Minnesota Law Review, 39, 493-516.

81. Garcia, V. (2005). Constructing the 'Other' within Police Culture: An Analysis of a Deviant Unit within the Police Organisation. Police Practice and Research, 6, 65-80.

82. Gearson, J. (2002). The Nature of Modern Terrorism. In Freedman, L. (editor). Superterrorism: Policy Responses. London: Blackwell, 7-24.

83. Gilligan, G. (2002). Royal Commissions of Inquiry. Australian and New Zealand Journal of Criminology, 35, 289-307.

84. Golding, B., \& Savage, S. (2008). Leadership and Performance Management. In Newburn, T. (editor). Handbook of Policing $2^{\text {nd }} e d$. Cullompton: Willan, ch.27.

85. Goldsmith, A. (editor). (1991). Complaints Against the Police: the Trend to External Review. Oxford: Clarendon Press.

86. Goldsmith, A. (1995). Necessary but Not Sufficient: the Role of Public Complaints Procedures in Police Accountability. In Stenning, P. (editor). Accountability for Criminal Justice: Selected Essays. Toronto: University of Toronto Press, 110.

87. Goldsmith, A. (1990). Taking Police Culture Seriously: Police Discretion and Limits of Law. Policing and Society, 91-114.

88. Goldsmith, A., \& Dineen, S. (2007). Transnational Police Building: Critical Lessons from Timor-Leste and Solomon Islands. Third World Quarterly, 28, $1091-1109$.

89. Goldsmith, A., \& Lewis, C. (editors). (2000). Civilian Oversight of Policing: Governance, Democracy and Human Rights. Portland: Oxford University Press.

90. Goldsmith, A., \& Sheptycki, J. (2007). Crafting Transnational Policing: Police Capacity-Building and Global Policing Reform. Oxford: Hart.

91. Goldstein, H. (1990). Problem Oriented Policing. New York: McGraw Hill.

92. Hadden, T. (editor). (2009). A Responsibility to Assist: Human Rights Policy and Practice in European Union Crisis Management Operations. Oxford: Hart 
93. Hadfield, B. (1999). $R v$ Lord Saville of Newdigate, ex parte Anonymous Soldiers: What is the Purpose of a Tribunal of Inquiry? Public Law, 663-681.

94. Hale, C., Heaton, R., \& Uglow, S. (2005). Uniform Styles? Aspects of Police Centralisation in England and Wales. Policing and Society, 15, 1-18.

95. Hamilton, C. (2007). The Presumption of Innocence in Irish Criminal Law. Dublin: Irish Academic Press.

96. Hamilton, J., Radford, K., \& Jarman, N. (2003). Policing, Accountability and Young People. Belfast: Institute for Conflict Research.

97. Hansen, A. (2004). Security and Defence: The EU Police Mission in BosniaHerzogovina. In Carlsneas, W., Sjursen, H., \& White, B. (editors). Contemporary European Foreign Policy. London: Sage.

98. Harfield, C. SOCA: a Paradigm Shift in British Policing. British Journal of Criminology, 46, 743-761.

99. Harfield, C., Grieve, T., MacVean, A., \& Phillips, D. (2008). Handbook of Intelligence Policing: Consilience, Crime Control and Community Safety. Oxford: Oxford University Press.

100. Hayes, M. (1997). A Police Ombudsman for Northern Ireland? A Review of the Police Complaints System in Northern Ireland. Belfast: Northern Ireland Office.

101. Hegarty, A. (2003). The Government of Memory: Public Inquiries and the Limits of Justice in Northern Ireland. Fordham International Law Journal $26,1148$.

102. Hinton, M., \& Newburn, T. (2009). Policing Developing Democracies. London: Routledge.

103. Holdaway, S. (2003). Police Race Relations in England and Wales: Theory, Policy and Practice. Police \& Society, 7, 49-75.

104. Home Office. (2004). Managing Police Performance: a Practical Guide to Performance Management. London: HMSO, 2004.

105. Hudson, J. (1973). Police Review Boards and Police Accountability. Law and Contemporary Problems, 36, 515-538.

106. Inbau, F. (1999). Law and Police Practice: Restrictions in the Law of Interrogation and Confessions. Journal of Criminal Law and Criminology, 89.

107. Independent Commission on Policing in Northern Ireland. (1999). A

New Beginning: Policing in Northern Ireland: Report of the Independent Commission on Policing for Northern Ireland (Patten Report). London: HMSO.

108. Inglis, T. (2003). Truth, Power and Lies: Irish Society and the Case of the Kerry Babies. Dublin: UCD Press.

109. Innes, M., \& Thiel, D. (2008). Policing Terror. In Newburn, T. (editor). Handbook of Policing $2^{\text {nd }}$ ed. Cullompton: Willan, ch.21.

110. Jacobi, J. (2000). Prosecuting Police Misconduct. Wisconsin Law Review, 4, 789-855.

111. Jefferson, T., \& Grimshaw, R. (1984). Controlling the Constable. London: Cobden Trust..

112. Johnston, L. (2000). Policing Britain: Risk, Security and Governance. London: Longman.

113. Johnston, L. (1999). Private Policing in Context. European Journal on Criminal Policy and Research, 7, 175-196.

114. Johnston, L. (1992). The Rebirth of Private Policing. London: Routledge. 
115. Johnston, L., \& Shearing, C. (2003). Governing Security. London: Routledge.

116. Johnston, T. (1966). The Judges' Rules and Police Interrogation in England Today. Police Science, 57.

117. Jones, T. (2008). The Accountability of Policing. In Newburn, T. (editor). Handbook of Policing $2^{\text {nd }}$ ed. Cullompton: Willan, ch.26

118. Jones, T. (2003). The Governance and Accountability of the Police. In Newburn, T. (editor). The Handbook of Policing. Cullompton: Willan.

119. Jones, T., \& Newburn, T. (1997). Policing after the Act: Police Governance after the Police and Magistrates' Courts Act 1994. London: Policy Studies Institute.

120. Jones, T., \& Newburn, T. (editors). (2006). Plural Policing: $a$ Comparative Perspective. Abingdon: Routledge.

121. Jones, T., Newburn, T. (1998). Private Security and Public Policing. Oxford: Clarendon Press.

122. Kaci, J. (1982). Confessions: A Comparison of Exclusion Under Miranda in the US and the Judges' Rules in England. American Journal of Criminal Law, 10, 87-112.

123. Kamisar, Y. (2003). In Defense of the Search and Seizure Exclusionary Rule" Harvard Journal of Law and Public Policy, 26, 119.

124. Keane, A. (2007). The Modern Law of Evidence $7^{\text {th }}$ ed. Oxford: Oxford University Press.

125. Kempa, M. (2007). Tracing the Diffusion of Police Governance Models for the British Isles and Back Again: Some Directions for Democratic Reform in Troubled Times. Police Practice and Research, 8, 127-123.

126. Kempa, M., \& Johnston, L. (2005). Challenges and Prospects for the Development of Inclusive Plural Policing in Britain: Overcoming Political and Conceptual Obstacles. Australian and New Zealand Journal of Criminology, $38,181-191$.

127. Kempa, M. et al. (1999). Reflections on the Evolving Concept of Private Security. European Journal on Criminal Policy and Research, 7, 197223.

128. Kerstetter, W.A. (1985). Who Disciplines the Police? Who Should? In Geller, W. Police Leadership in America: Crisis and Opportunity. New York: Praeger.

129. Kleinig, J. (1996). The Ethics of Policing. Cambridge: Cambridge University Press.

130. The Knapp Commission Report on Police Corruption. (1973). New York: Braziller.

131. Kratcoski, P.C., \& Das, D.K. (editors). (2007). Police Education and Training in a Global Society. Maryland: Lexington Books.

132. Leigh, L.H. (1975). Police Powers in England and Wales. London: Butterworths.

133. Levi, M., \& Maguire, M. (1992). Crime and Cross Border Policing in Europe. London: Longman.

134. Lewis, C. (1999). Complaints against the Police: the Politics of Reform. Sydney: Hawkins Press.

135. Lindell, G. (2000). Tribunals of Inquiry and Royal Commissions. Sydney: Federation Press. 
136. Lister, S. (2006). Painting the Town Blue: The Pluralisation of Policing. Criminal Justice Matters, 63, 22-23.

137. Loader, I. (2002). Governing European Policing: Some Problems and Prospects. Policing and Society, 12, 291-305.

138. Loader, I. (2000). Plural Policing and Democratic Governance. Social and Legal Studies, 9, 323-345.

139. Loader, I. (2002). Policing, Securitisation and Democratisation in Europe. Criminology and Criminal Justice, 2, 125-153.

140. Loader, I., \& Walker, N. (2007). Civilising Security. Cambridge: Cambridge University Press.

141. Loftus, B. (2009). Police Culture in a Changing World. Oxford: Oxford University Press.

142. Loveday, B. (2000). New Directions in Accountability. In Leishman, F. et al. (editors). Core Issues in Policing. Harlow: Longman, 213-231.

143. Loveday, B. (1988). Police Complaints in the USA. Policing, 4(3), 172-193.

144. Lustgarten, L. (1986). The Governance of Police. London: Sweet \& Maxwell.

145. Lutterbeck, D. (2004). Between Police and Military: The New Security Agenda and the Rise of Gendarmeries. Cooperation and Conflict, 39, $45-68$.

146. Lutterbeck, D. (2005). Blurring the Dividing Line: The Convergence of Internal and External Security in Western Europe. European Security, 14, 231-253.

147. Macpherson, W. (1999). The Stephen Lawrence Inquiry. London: HMSO.

148. Maguire, M., \& Corbett, C. (1991). A Study of the Police Complaints System. London: PACE.

149. Manning, P. (1980). Narcs Game: Organisational and Informational Limits on Drug Law Enforcement. Massachusetts: MIT Press..

150. Manning, P. (2008). Technology of Policing: Crime Mapping,

Information Technology and the Rationality of Crime Control. New York: New York University Press.

151. Marenin, O. (2005). Restoring Policing Systems. In Conflict Torn

Nations: Process, Problems and Prospects. Geneva: Geneva Centre for

Democratic Control of Armed Forces.

152. Mark, R. (1979). In the Office of Constable. London: Fontana.

153. Mark, R. (1977). Policing a Perplexed Society. London: Allen \& Unwin.

154. Marshall, G. (1978). Police Accountability Revisited. In Butler, D., \& Halsey, A.H. (editors). Policy and Politics: Essays in Honour of Norman Chester. London: Macmillan.

155. Marshall, G. (1965). Police and Government. London: Methuen.

156. Mawby, R.I. (2008). Models of Policing. In Newburn, T. (editor) Handbook of Policing $2^{\text {nd }}$ ed. Cullompton: Willan.

157. Mendes, E., Zuckerberg, J., Lecorre, S., Gabriel, A., \& Clark, J. (1999). Democratic Policing and Accountability: Global Perspectives.

Aldershot: Ashgate.

158. McLagan, G. (2006). Bent Coppers: The inside story of Scotland Yard's battle against police corruption. London: Orion Press.

159. McLaughlin, E. (2007). The New Policing. London: Sage. 
160. McLaughlin, E., \& Johansen, A. (2002). A Force for Change? The

Prospects of Applying Restorative Justice to Citizen Complaints Against the

Police in England and Wales. British Journal of Criminology, 42, 635-653.

161. Merlinger, M., \& Ostrauskite, R. (2005). Power/Knowledge in International Peacebuilding: The Case of the EU Mission in Bosnia.

Alternatives: Global, Local, Political, 30, 297-323.

162. Miller, S. (editor). (2006). Police Ethics. Aldershot: Ashgate.

163. Morgan, R. (1986). Police Consultative Groups: the Implications for the Governance of the Police. Political Quarterly, 57.

164. Mulcahy, A. (2006). Policing Northern Ireland: Conflict, Legitimacy and Reform. Cullompton: Willan.

165. Mulqueen, M. (2009). Securing the State with Soldier Spies:

evaluating the Risks of using Military Personnel to gather Surveillance" evaluating the Risks of using Military Personnel to gather Surveillance

Evidence in Ireland. Irish Studies in International Affairs, 20, 121-141.

166. Newburn, T. (1999). Understanding and Preventing Police

Corruption: Lessons from the Literature. London: Home Office Policing and Reducing Crime Unit.

167. Newburn, T., \& Jones, T. (1996). Police Accountability. In Saulsbury, W., Mott, J., \& Newburn, T. (editors). Themes in Contemporary Policing.

London: Policy Studies Institute.

168. Newham, G. (2000). Transformation and the Internal Disciplinary System of the South African Police Force. Criminal Justice, [REF]

169. Neyroud, P. (2008). Policing and Ethics. In Newburn, T. (editor). Handbook of Policing $2^{\text {nd }}$ ed. Cullompton: Willan, ch.25;

170. Neyroud, P. (2001). Public Participation in Policing. London: Institute for Public Policy Research.

171. Neyroud, P., \& Beckley, A. (2001). Policing, Ethics and Human Rights. Collumpton: Willan.

172. Nogala, D. (2001). Policing Across a Dimorphous Border: Challenge and Innovation at the French-German Border. European Journal of Crime, Criminal Law and Criminal Justice, 9, 130-143.

173. Occhipinti, J.D. (2003). The Politics of European Union Police Cooperation: Toward a European FBI? Boulder Colorado: Lynne Rienner.

174. Optican, S., \& Sankoff, D. (2003). The New Exclusionary Rule: a Preliminary Assessment of $R v$ Shaheed. New Zealand Law Review, 1-44.

175. Paoline, E.A. (2003). Taking Stock: Towards a Richer Understanding of Police Culture. Journal of Criminal Justice, 31, 199-214.

176. Paulson, M. (1961). The Exclusionary Rule and Misconduct by the Police. The Journal of Criminal Law, Criminology and Police Science, 52, 255-265.

177. Pickering, S. (2004). Border Terror: Policing Forced Migration and Terrorism. Global Change, Peace and Security 14, 211-216.

178. Plachta, M. (2005). Joint Investigation Teams: A New Form of International Cooperation. European Journal of Crime, Criminal Law and Criminal Justice, 13, 184-302.

179. Prenzler, T. (2008). Is There a Police Culture? Australian Journal of Public Administration, 56(4), 47-56.

180. Prenzler, T., \& Ransey, J. (editors). (2002). Police Reform: Building Integrity. Sydney: Hawkins Press. 
181. Prenzler, T., \& Sarre, R. (1998). Regulating Private Policing in Australia. Trends and Issues in Crime and Criminal Justice, 98, 1-6.

182. Punch, M. (2009). Police Corruption: Deviance, Accountability and Reform in Policing. Cullompton: Willan.

183. Punch, M. (2000). Police Corruption and its Prevention. European Journal on Criminal Policy and Research, 8, 301.

184. Reiner, R. (1992). Policing a Post-Modern Society. Modern Law Review, 55, 761-781.

185. Reiner, R. (2010). The Politics of the Police $4^{\text {th }} \mathrm{ed}$. Oxford: Oxford University Press.

186. Reith, C. (1952). The Blind Eye of History. London: Faber \& Faber.

187. Report of the Commission of Investigation (Dean Lyons Case). (2006)

Dublin: Stationery Office.

188. Report of the Inquiry into Possible Illegal Activities and Associated

Police Misconduct (The Fitzgerald Report). (1989). Government of

Queensland.

189. Report of the Royal Commission on the Police. (1962). London:

HMSO, Cmnd.1728.

190. Report of the Royal Commission on Tribunals of Inquiry (The Salmond Commission). London: HMSO, Cmnd.3121.

191. Report of the Tribunal of Inquiry into the Facts and Circumstances Surrounding the Fatal Shooting of John Carthy at Abbeylara, Co. Longford on $20^{\text {th }}$ April, 2000. (2006). Dublin: Stationery Office.

192. Report of the Tribunal of Inquiry into "The Kerry Babies Case". (1985). Dublin: Stationery Office.

193. Reports of the Tribunal of Inquiry Set up Pursuant to the Tribunals of Inquiry (Evidence) Acts 1921-2002 into Certain Gardaí in the Donegal Division. (2004-2008). Dunlin: Stationery Office.

194. Reuss-Ianni, E. (1993). Two Cultures of Policing: Street Cops and Management Cops. New Jersey: Transaction Publishers.

195. Rijken, C. (2006). Joint Investigation Teams: principles, practice, and problems: Lessons learnt from the first efforts to establish a JIT. Utrecht Law Review, 2, 99-118.

196. Rijken, C., \& Vermuelen, G. (2006). Joint Investigation Teams in the European Union: From Theory to Practice. The Hague: TMC Asser Press.

197. Roach, K. (1995). Canadian Public Inquiries and Accountability. In Stenning, P. (editor). Accountability for Criminal Justice: Selected Essays. Toronto: University of Toronto Press, 268.

198. Rowe, M. (2009). Notes on a Scandal: The Official Enquiry into Deviance and Corruption in the New Zealand Police. Australian and New Zealand Journal of Criminology, 42, 123-138.

199. Rowe, M. (editor). (2007). Policing beyond Macpherson: Issues in Policing, Race and Society. Cullompton: Willan.

200. Sampson, F., \& de Silva, N. (2001). Police Conduct, Complaints and Efficiency. Oxford: Oxford University Press.

201. Sanders, A., \& Young, R. (2008). Police Powers. In Newburn, T. (editor). Handbook of Policing $2^{\text {nd }}$ ed. Cullompton: Willan, ch.12.

202. Savage, S. (2007). Police Reform: Forces for Change. Oxford: Oxford. University Press. 
203. Savage, S., Charman, S., \& Cope, S. (1996). Police Governance, the Association of Chief Police Officers and Constitutional; Change. Public Policy and Administration, 11, 92-106.

204. Scarman, B. (1981). Report on the Disturbances in Brixton 10th to 13th April 1981. London: HMSO.

205. Schalken, T., \& Pronk, M. (2002). On Joint Investigation Teams, Europol and the Supervision of Their Joint Actions. European Journal of Crime, Criminal Law and Criminal Justice, 10, 70-82.

206. Scraton, P. (2004). From Deceit to Disclosure: The Politics of Official Inquiries in the United Kingdom. In Gilligan, G., \& Pratt, J. (editors). Crime, Truth and Justice. Cullompton: Willan.

207. Scraton, P. (1985). The Police State we are in. London: Pluto Press.

208. Serafino, N. (2007). Policing in Peacekeeping and Related Stability Operations: Problems and Proposed Solutions. In Gerbick, K. (editor). Peacekeeping and Stability Issues. New York: Nova Science.

209. Shearing, C., \& Stenning, P. (1981). Modern Private Security: its Growth and Implications. In Tonry, M. Morris, N. (editors). Crime and Justice: an Annual Review of Research. Chicago: University of Chicago Press, 193-245.

210. Shearing, C., \& Stenning, P. (1985). Private Security: Implications for Social Control. Social Problems, 3, 493-506.

211. Sheptycki, J. (2002). Accountability Across the Policing Field:

Towards a General Cartography of Accountability for Post-Modern Policing.

Policing and Society, 12, 323-338.

212. Sheptycki, J. (1998). The Global Cops Cometh; Reflections on

Transnationalisation, Knowledge Work and Police Subculture. British Journal of Sociology, 49, 57-74.

213. Sheptycki, J. (2002). In Search of Transnational Policing: a Sociology of Global Policing. Aldershot: Ashgate.

214. Sheptycki, J. (editor). (2000). Issues in Transnational Policing. London: Routledge.

215. Sheptycki, J. (2001). Patrolling the New European (In)Security Field; Organisational Dilemmas and Operational Solutions for Policing the Internal Borders of Europe. European Journal of Crime, Criminal Law and Criminal Justice, 9, 144.

216. Sheptycki, J. (1998). Police Cooperation in the English Channel Region 1968-1996. European Journal of Crime, Criminal Law and Criminal Justice, 6, 216.

217. Sheptycki, J. (2000). Policing and Human Rights: An Introduction. Policing and Society, 10, 1-10.

218. Sklansky, D. (2008). Democracy and the Police. Stanford: Stanford University Press.

219. Sklansky, D.A. (2007-08). "Is the Exclusionary Rule Obselete? Ohio State Journal of Criminal Law, 5, 567.

220. Sklansky, D. (2006). Private Police and Democracy. American Criminal Law Review, 43, 89-106.

221. Skolnick, J., \& Fyffe, J. (2005). The Beating of Rodney King. In Newburn, T. (editor). Policing: Key Readings. Cullompton: Willan, ch.33. 222. Smith, G. (2003). Actions for Damages Against the Police and Attitudes of Claimants. Policing and Society, 13(4), 413-422. 
223. Smith, G. (2006). A most enduring problem: police complaints reforms in England and Wales. Journal of Social Policy, 35.

224. Smith, G. (2001). Police Complaints and Criminal Prosecutions. Modern Law Review, 64, 372-392.

225. Smith, G. (2004). Rethinking Police Complaints. British Journal of Criminology, 44, 15.

226. Spitzer, S., \& Skull, A. (1977). Privatization and Capitalist Development: The Case of the Private Police. Social Problems, 25, 18-29.

227. Stenning, P. (editor) (1995). Accountability for Criminal Justice: Selected Essays. Toronto: University of Toronto Press.

228. Stenning, P. (2009). Governance and Accountability in a Plural Policing Environment: The Story So Far. Policing, 22-33.

229. Stenning, P. (2007). The Idea of the Political 'Independence' of the Police: International Interpretations and Experiences". In Beare, M., \& Murray, T. (editors). Police \& Government Relations: Who's Calling the Shots? Toronto: University of Toronto Press.

230. Stenning, P. (1981). Legal Status of the Police. Ottawa: Law Commission of Canada..

231. Stenning, P. (2000). Powers and Accountability of Private Police. European Journal of Criminal Policy and Research. 8, 325-352.

232. Tilley, N. (2008). Modern approaches to policing: community, problem-oriented and intelligence led. In Newburn, T. (editor) Handbook of Policing $2^{\text {nd }} e d$. Cullompton: Willan, ch.15.

233. Tobias, J. (1979). Crime and Police in England 1700-1900. New York: St Martins Press.

234. Transnational Institute in association with Statewatch. (2009).

NeoConOpticon: The EU Security-Industrial Complex. Online, available at http://www.statewatch.org/analyses/neoconopticon-report.pdf.

235. Uchida, C., \& Bynum, T. (1991). Search Warrants, Motions to Suppress and 'Lost Causes': the Effects of the Exclusionary Rule in Seven Jurisdictions. Journal of Criminal Law and Criminology, 1034-1066.

236. Uglow, S. (1988). Policing Liberal Society. Oxford: Oxford University Press.

237. Uldriks, N., \& Van Reenen, P. (2003). Policing Post-Communist

Societies: Police-Public Violence, Democratic Policing and Human Rights.

Antwerp: Intersentia.

238. Van Steden, R. (2007). Privatising Policing: Describing and

Explaining the Growth of Private Security. Amsterdam: BJu Legal Publishers.

239. Verma, A. (2000). Politicisation of the Police in India: Where Lies the

Blame? Indian Police Journa,1 47, 9-37.

240. Vickers, M., \& Kouzmin, A. (2001). New Managerialism and

Australian Police Organisations. International Journal of Public Sector Management, 14, 7-26.

241. Waddington, P.A.J. (1988). Arming an Unarmed Police: Policy and Practice in the Metropolitan Police. London: The Police Foundation.

242. Waddington, P.A.J. (1999). Police (canteen) Sub-culture: An Appreciation. British Journal of Criminology, 39, 287-309.

243. Waddington, P.A.J. (1999). Policing Citizens: Authority and Rights. London: UCL Press. 
244. Waddington, P.A.J. (1991). The Strong Arm of the Law: Armed and Public Order Policing. Oxford: Oxford University Press.

245. Waddington, P.A.J., \& Wright, M. (2008). Police Use of Force, Firearms and Riot Control. In Newburn, T. (editor). Handbook of Policing $2^{\text {nd }}$ ed (Cullompton: Willan, ch.18.

246. Wakefield, A. (2003). Selling Security. Cullompton: Willan.

247. Walker, N. (2008). The Pattern of Transnational Policing. In Newburn, T. (editor). Handbook of Policing $2^{\text {nd }} e d$. Cullompton: Willan, ch.7.

248. Walker, N. (2000). Policing in a Changing Constitutional Order. London: Sweet \& Maxwell.

249. Walsh, D.P.J. (2000). Bloody Sunday and the Rule of Law in Northern Ireland. London: Macmillan.

250. Walsh, D.P.J. (2007). The Criminal Justice Act 2006: A Crushing Defeat for Due Process Values? Judicial Studies Institute Journal, 7, 44-59.

251. Walsh, D.P.J. (2009). Human Rights and Policing in Ireland: Law, Policy and Practice. Dublin: Clarus Press.

252. Walsh, D.P.J. (1998). The Irish Police: A Legal and Constitutional Perspective. Dublin: Round Hall Sweet \& Maxwell.

253. Walsh, DP.J. (2004). The Proposed Garda Complaints Procedure: A Critique". Irish Criminal Law Journal, 14, 2-26.

254. Walsh, D.P.J. (2009). Twenty Years of Handling Police Complaints in Ireland: a Critical Assessment of the Supervisory Board Model. Legal Studies, 39, 305-337.

255. Waters, I. (2000). Quality and Performance Monitoring. In Leishman, F., Loveday, B., \& Savage, S. (editors). Core Issues in Policing $2^{\text {nd }} e d$. Harlow: Pearson.

256. Waters, I., \& Brown, K. (2000). Police Complaints and the Complainants Experience. British Journal of Criminology, 40, 1.

257. West, P. (1998). Investigation of Complaints against the Police:

Summary Report of a National Survey. American Journal of Police, 7, 101.

258. Westmarland, L. (2001). Gender and Policing: Sex, Power and Police Culture. Cullompton: Willan.

259. Westmarland, L. Police Cultures. In Newburn, T. (editor). Handbook of Policing $2^{\text {nd }}$ ed. Cullompton: Willan, ch.11.

260. Westmarland, L. (2005). Police Ethics and Integrity: Breaking the Blue Code of Silence. Policing and Society, 15, 145-165.

261. Williams, R. (2008). Policing and Forensic Science. In Newburn, T. (editor) Handbook of Policing $2^{\text {nd }}$ ed. Cullompton: Willan, ch.28.

262. Zedner, L. (2006). Policing before and after the Police. British Journal of Criminology, 46, 78-96. 